Potravinarstvo Slovak Journal of Food Sciences vol. 14, 2020, p. 112-117

https://doi.org/10.5219/1192

Received: 12 September 2019. Accepted: 29 December 2019.

Available online: 28 February 2020 at www.potravinarstvo.com

(C) 2020 Potravinarstvo Slovak Journal of Food Sciences, License: CC BY 3.0

ISSN 1337-0960 (online)

\title{
NUTRITIONAL AND BIOLOGICAL VALUE OF PORK OBTAINED FROM ANIMALS FED WITH LYSINE AND METHIONINE
}

\author{
Ivan Gorlov, Marina Slozhenkina, Alexander Mosolov, Vladimir Baranikov, Dmitry Nikolaev, \\ Alexander Chernyak, Bogdan Sherstyuk, Olga Krotova
}

\begin{abstract}
The article presents material on the effect of the amino acids lysine and methionine in pig diets. Studies have been carried out to increase the live weight of animals, depending on the content of these amino acids in the diet when fattening up to 100 and $120 \mathrm{~kg}$. Presented research results obtained during testing in certified and accredited laboratories. When growing gilts to live weight from 30 to $50 \mathrm{~kg}$, a deficiency in the level of lysine was found, which reaches up to $29.6 \%$, and methionine with cystine up to $23.1 \%$. When growing animals from 81 to $120 \mathrm{~kg}$ of live weight, the lysine deficiency is $14.9 \%$, and methionine with cystine is $8,8 \%$. This necessitated balancing the diet of animals to the required level of amino acid content. The most effective on the growth and development of animals, as well as on indicators of pork quality, was the introduction of feed lysine in combination with methionine in pig diets.
\end{abstract}

Keywords: lysine; methionine with cystine; gilts; live weight; rations

\section{INTRODUCTION}

At present, the pig-breeding industry in the Russian Federation is developing quite dynamically and domestic pork production reaches more than $95 \%$ of the volume consumed, which provides the population of the country per person $26 \mathrm{~kg}$ of this type of product. However, in countries of world pork exporters in the USA, England, Germany, Canada, Denmark, Italy, Spain, more than 100 $\mathrm{kg}$ of meat is produced per person. Therefore, in Russia there is a need to further increase the production of pig meat, including not only through the use of breeding and genetic innovations, but also to improve animal breeding by improving the quality of feeding rations (Mysik, 2008; Strekozov and Chinarov, 2012). Full and balanced nutrition of pigs in all nutrients is the key not only to a steady increase in meat productivity of animals, but also their reproductive qualities, as well as physiological development at all stages of growth (Kukushkin and Filatov, 2011; Belous et al., 2018; Kulintsev, 2011; Nikonkov et al., 2015; Kumar et al., 2012; Smith et al., 1999).

The aim of the research was to study the effect of diets with a low protein level in pig diets, which is typical for the southern regions of our country, on the physiological parameters of animals, as well as on fattening and meat qualities of young animals.

\section{Scientific hypothesis}

Supplementation of lysine and methionine in pig diet will increase production of pork. In connection with the foregoing, it is advisable to conduct research aimed at studying the effect of the introduction of the amino acids lysine and methionine with cystine on the physiological development of animals, growth, development of young pigs, as well as on increasing production of pork.

\section{MATERIAL AND METHODOLOGY}

The studies were conducted at the Lenin collective farm breeding farm in the Surovikinsky district of the Volgograd region in the period from 2017 to 2019. For testing, 3 groups of purebred gilts of large white breed, 16 animals each, obtained as a result of the second farrow, were selected. Gilts were selected according to the principle of analogue pairs, considering gender, age, and physiological state. For the experiment, the feeding process was divided into three periods. The first period is from 30 to $50 \mathrm{~kg}$ of live weight; the second period is from $51-80 \mathrm{~kg}$ and the third period are from 81 to $120 \mathrm{~kg}$ of live weight. Control slaughter of experimental animals was carried out when 100 and $120 \mathrm{~kg}$ of live weight were achieved.

The animals were grown according to the zootechnical standarts adopted in Russia. According to the recommendations of the all-russian institute of animal 
husbandry, the balance sheet experience was divided into preparatory and main periods. The preparatory period was carried out for 21 days, animals of all experimental groups received the main diet. The study of the balance of the diets of feeding experimental animals was carried out on the basis of the analysis of the actual diet by the content of protein, lysine, methionine with cystine in it at the Volgograd Regional Veterinary Laboratory, a comprehensive analytical laboratory of the State Scientific Research Institute of Nuclear Medicine and Pediatrics, and Volgograd. The analysis of the chemical composition of feed and animal metabolic products was carried out according to generally accepted methods of zootechnical analysis (Alikaev et al., 1967; Zlebedev and Usovich, 1976). In all experimental groups, animals were fed using concentrated feeds (concentrate type of feeding). The first group received the main diet, while the content of digestible protein fluctuated in weighted periods of $119 \mathrm{~g}$, $106 \mathrm{~g}$ and $98 \mathrm{~g}$, respectively. To adjust the balance of diets for essential amino acids, they were carried out using a mixture of peas and meat and bone meal, and the lack of carotene in the diet was ensured by the introduction of alfalfa flour. Gilts of the second and third groups received the main diet. At the same time, animals of the second group to compensate for the lack of lysine received feed lysine, which was prepared according to GOST R 569132016, and in the third group, the lack of lysine and methionine was compensated by feed lysine with the addition of methionine. Additionally, chalk and sodium chloride were added to the diets of animals of all experimental groups to provide them with calcium, sodium and chlorine. General economic rations for the periods of experiment consisted of 98.2 concentrated feed and $1.8 \%$ roughage in the first period; in the second period concentrated feed - by $98.6 \%$ and roughage - by $1.4 \%$, in the third period - concentrated feed - by $98.6 \%$ and roughage - by $1.4 \%$. The analysis of the content in the meat samples of experimental animals was studied on the basis of data obtained on an amino acid analyzer model (L8800, "Hitachi", Ltd). The content of amino acids and minerals is shown in Figure 1.

Analyzing the data presented in Figure 1, we can draw the following conclusion: in the first period of the experiment, the deficiency of the diets of experimental gilts for digestible protein is $19.0 \%$, lysine - $34.9 \%$, methionine with cystine $-37,8 \%$; for the second period by $14.4 ; 29.6 ; 23.1 \%$, respectively; in the third period, there was a deficiency in the amino acid lysine $-14.9 \%$, methionine with cystine $-8.8 \%$. The experimental gilts were kept separately in groups, feeding was carried out twice. The necessary amino acids (in dry form) were introduced into the feed mixture stepwise after thorough mixing in the diets of experimental gilts. A study of the growth and development of gilts was established on the basis of taking into account the monthly increase in live weight. Before the control slaughter of the experimental animals, weighing was carried out after 24 hours of fasting. Assessment of meat productivity of animal carcasses was studied in accordance with the "All-Russian Institute of animal Husbandry Methodological Recommendations for the assessment of meat productivity, quality of meat and subcutaneous fat of pigs". Sampling of the longest muscle of the back and adipose tissue was

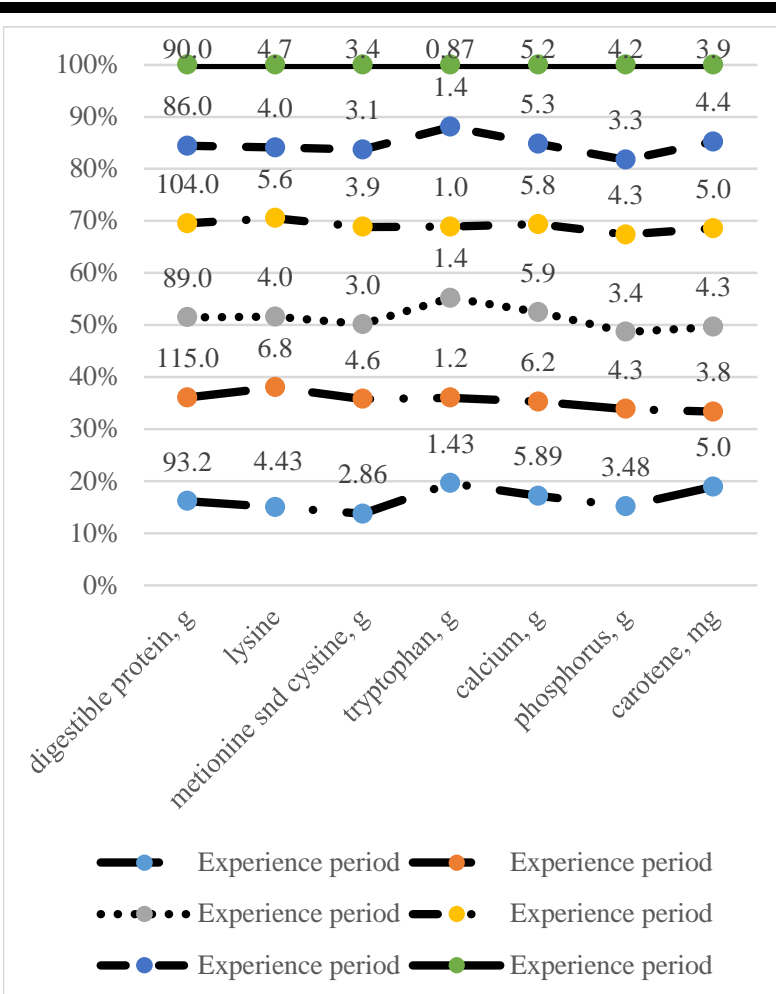

Figure 1 Diets of experimental animals.

carried out at a level between the $9^{\text {th }}$ and $12^{\text {th }}$ thoracic vertebrae, after cooling at a temperature of $2-4{ }^{\circ} \mathrm{C}$ in the refrigerator for 24 hours.

In order to more fully evaluate the meat qualities of experimental gilts after 24-hour exposure, the right half carcasses were deboned. At the same time, the weight of the ham, the ratio of meat, fat and bones, the area of the "muscle eye", determined on the cross section of the longest muscle of the back between the last pectoral and first lumbar vertebrae, were evaluated. Tasting evaluation of the broth and meat obtained from experimental animals was evaluated on the basis of organoleptic evaluation according to GOST 9959-91 "Meat products. General conditions for organoleptic assessment".

\section{Statistic analysis}

The data obtained during the experiments were processed using mathematical methods of variation statistics using the Microsof Excel software and Statistika 6 developer: StatSoft, USA. In the course of our work, we used the Student-Fisher method. For to assess the effect of lysine and methionine content in animal diets during different periods of their growth. The first threshold of reliability of the obtained data is designated as $(p \geq 0.95)$; the second ( $p \geq 0.99)$; the third $(p \geq 0.999)$, and if the results are not reliable, then $(p \leq 0.95)$.

\section{RESULTS AND DISCUSSION}

The results of the dynamics of the live weight of experimental gilts are presented in Table 1. As we can see from the data in Table 1 , animals of the $1^{\text {st }}$ group were superior to analogues from groups 2 and 3 in live weight at 4,5 and 6 months by $6.21(p \geq 0.95)$ and $2.22 \% ; 5.62$ $(p \geq 0.95)$ and $2.65 \%$ and $6,41 \quad(p \geq 0.95)$ and $1.19 \%$, respectively. However, when fattening up to $100 \mathrm{~kg}$ of live weight, the highest weight was achieved in group 2, which 
is 0.60 and $0.20 \%$ higher in comparison with groups 1 and 3. Upon reaching $120 \mathrm{~kg}$, the highest weight was observed in animals of the $3^{\text {rd }}$ group, which is 0.33 and $0.83 \%$ more, respectively, in comparison with the $1^{\text {st }}$ and $2^{\text {nd }}$ groups. Based on the results of monthly weighings, the average daily gain in live weight was calculated, the data are presented in Figure 2.

As we can see from the data of Figure 2 and Figure 3, despite the fact that the average daily gain in live weight in animals of groups 2 and 3 at 5 months of age when reaching 100 and $120 \mathrm{~kg}$ of live weight was lower than in analogues of group 1 - by 97 and $40 \mathrm{~g} ; 37$ and $27 \mathrm{~g}$ and 28 and $13 \mathrm{~g}$, the age of reaching 100 and $120 \mathrm{~kg}$ was less when reaching $100 \mathrm{~kg}$ of live weight by 9 and 5 days, when reaching $120 \mathrm{~kg}$, animals of the 2 nd group exceeded the analogues of the 1 st group by 11 days, and analogues of 3 groups spent less by 24 days. It should be noted that the balance of plant general rations allows to significantly $(p \geq 0.95)$ reduce feed costs (Figure 4$)$. From the presented Figure 4 it can be seen that in animals of groups 2 and 3, when fattening up to $100 \mathrm{~kg}$, the absolute increase in live weight increased in comparison with the analogues of group 1 by $1.5 \mathrm{~kg}$, or $2.1 \%$ and $0.8 \mathrm{~kg}$, or $1.13 \%$, feed costs increased by 0.39 units, or $8.99 \%(p \geq 0.95)$ and 0.13 units, or $3.04 \%$. The results obtained allow us to conclude that the use of the amino acids lysine and methionine in general diets can help to reduce the cost of feed per unit of growth and this helps to save feed, and also helps to increase the efficiency of pork production. As a result of the control slaughter of the experimental animals, we studied the meat qualities of the experimental young animals, which are presented in Table 2. The presented results in Table 2 indicate that the qualitative indicators were at the same level and did not have significant differences $(p \leq 0.95)$. It is worth noting that when fattening up to $100 \mathrm{~kg}$ in meat of gilts of group 3, the meat yield was higher in comparison with groups 1 and 2 by 0.5 and $0.8 \%$, and the protein-quality indicator (BPC) i.e. the ratio of the essential amino acid tryptophan to the essential amino acid oxyproline is 0.02 and $0.08 \%$ higher in animal meat. According to the area of the muscle eye, the meat of animals of the $1^{\text {st }}$ group is the best indicator, which is higher than in the $2^{\text {nd }}$ and $3^{\text {rd }}$ groups by 0.5 and $0.4 \mathrm{~cm}^{2}$.
In addition, we analyzed the amino acid scores of pork obtained from experimental gilts. For comparison, three samples were taken from half carcasses of groups 1,2, and 3. For a comparative assessment, the content of the most deficient amino acids of tryptophan, methionine + cystine and lysine was studied in meat.

By comparing the reference protein recommended by the FAO/WHO with experimental data, the following results were obtained: $1.29 \mathrm{~g} .100 \mathrm{~g}^{-1}$ of protein was contained in meat obtained from tryptophan group 1 animals; methionine + cystine $-3.58 \mathrm{~g} .100 \mathrm{~g}^{-1}$ protein; lysine $5.31 \mathrm{~g} .100 \mathrm{~g}^{-1}$ protein, which is less in comparison with analogues of groups 2 and 3 in tryptophan - by 3.9 and $7.7 \%$; methionine + cystine - by 2.2 and $2.8 \%$; lysine - by 1.9 and $6.0 \%$, respectively.

The studies presented showed that in the meat of animals of group 1, the amino acid rate was the smallest and amounted to $96.9 \%$, and in the meat of animals of groups 2 and $3-103.8$ and $105.6 \%$. In order to establish the nutritional value of pork obtained during research, an organoleptic assessment of broths was carried out on a 5-point scale with the participation of 15 tasters. Based on the appearance of the meat broths, the tasters determined that the broth prepared from pork of the 1st group scored the highest score -5.49 .

Assessing the appearance of meat broths, experts found that the broth obtained from the meat of gilts of the experimental group I scored the highest score -5.49 . At the same time, it was inferior in terms of aroma, taste, richness and overall rating, the broth of group 3 received the highest scores. The second place was established during the tasting of the broth of group 2 (Table 3 ).

Tasters found that in terms of appearance, aroma, taste, texture, juiciness and overall rating, the best results among the studied groups were boiled meat of gilts of group I. The second place, according to the general assessment, was obtained by the meat of gilts of the $3^{\text {rd }}$ group. In Smith (1999), it is noted that increasing the content of amino acids, including metinin and cystine, in the diets of pigs affects not only the improvement of digestibility of nutrients, but also the energy value of the diet.

Table 1 Dynamics of live weight of experimental gilts, $\mathrm{kg}(\mathrm{n}=16)$.

\begin{tabular}{ccccccc}
\hline \multirow{2}{*}{ Group } & \multicolumn{5}{c}{ Live weight } \\
\cline { 2 - 7 } & \multirow{2}{*}{ when fattening } & \multicolumn{3}{c}{ at the age of months } & $\mathbf{6}$ & when removing from fattening kg \\
\cline { 2 - 7 } & & $\mathbf{4}$ & $\mathbf{5}$ & $\mathbf{6}$ & $\mathbf{1 0 0}$ & $\mathbf{1 2 0}$ \\
\hline 1 & $29.7 \pm 0.40$ & $45.1 \pm 0.95^{*}$ & $64.1 \pm 1.22^{*}$ & $84.2 \pm 1.55^{*}$ & $99.8 \pm 3.18$ & $119.9 \pm 3.28$ \\
2 & $29.8 \pm 0.46$ & $42.3 \pm 0.98$ & $60.5 \pm 1.08$ & $78.8 \pm 1.68$ & $100.4 \pm 2.44$ & $119.3 \pm 3.68$ \\
3 & $29.9 \pm 0.48$ & $44.1 \pm 0.98$ & $62.4 \pm 1.06$ & $83.2 \pm 1.14^{*}$ & $100.2 \pm 3.02$ & $120.3 \pm 4.20$ \\
\hline
\end{tabular}

Table 2 Qualitative indicators of pork obtained from experimental gilts.

\begin{tabular}{ccccc}
\hline Group & Muscle eye area, cm & Ham weight, kg & Meat yield, \% & BKP, \% \\
\hline \multicolumn{7}{c}{ When fattening to mass 100 kg } \\
\hline 1 & $28.3 \pm 0.20$ & $9.22 \pm 0.30$ & $53.0 \pm 1.0$ & 8.00 \\
2 & $27.8 \pm 0.22$ & $9.16 \pm 0.30$ & $52.7 \pm 1.0$ & 7.92 \\
3 & $27.9 \pm 0.24$ & $9.22 \pm 0.20$ & $53.5 \pm 1.3$ & 8.02 \\
\hline 1 & $30.3 \pm 0.18$ & When fattening to mass 120 kg & 7.90 \\
2 & $29.9 \pm 0.28$ & $11.42 \pm 0.40$ & $49.8 \pm 1.0$ & 7.72 \\
3 & $30.3 \pm 0.20$ & $11.39 \pm 0.40$ & $52.6 \pm 1.2$ & 7.80 \\
\hline
\end{tabular}


Table 3 Organoleptic evaluation of meat broth, score.

\begin{tabular}{lccc}
\hline \multirow{2}{*}{ Indicator } & \multicolumn{3}{c}{ Group } \\
\cline { 2 - 4 } & I experienced & II experienced & III experienced \\
\hline Appearance & 5.49 & 5.38 & 5.44 \\
Aroma & 4.61 & 4.64 & 4.68 \\
Taste & 4.53 & 4.66 & 4.73 \\
Richness & 4.47 & 4.55 & 4.66 \\
Overall raiting & 4.78 & 4.81 & 4.88 \\
\hline
\end{tabular}

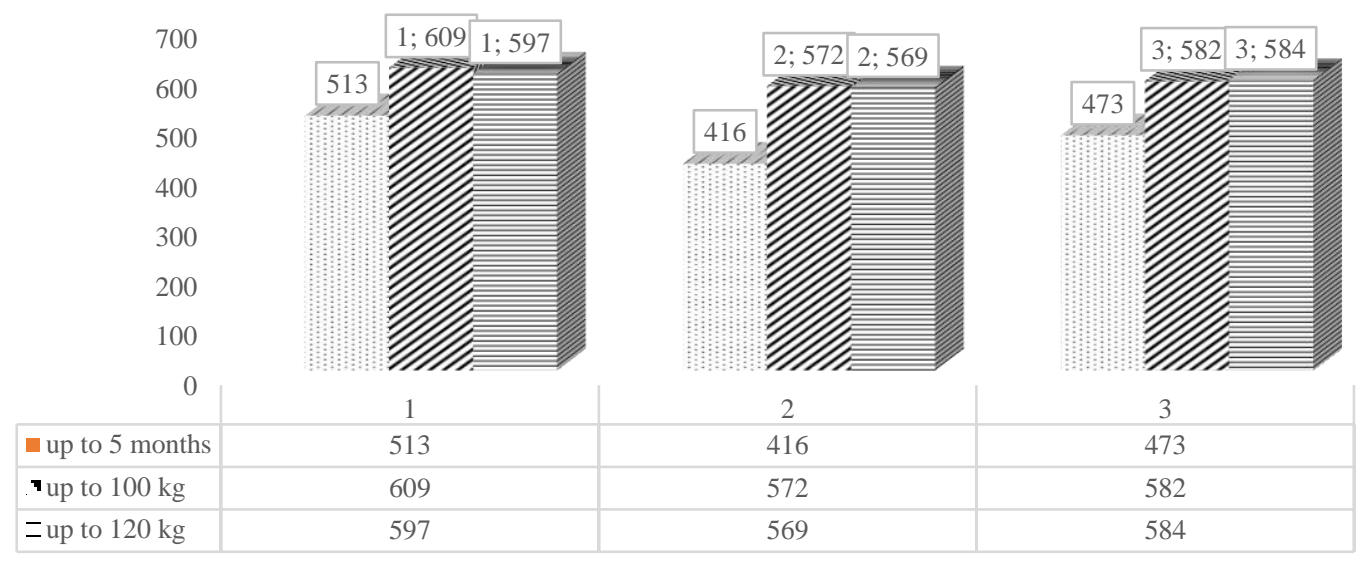

Figure 2 The average daily gain in live weight of experimental guinea pigs $(\mathrm{g})$.

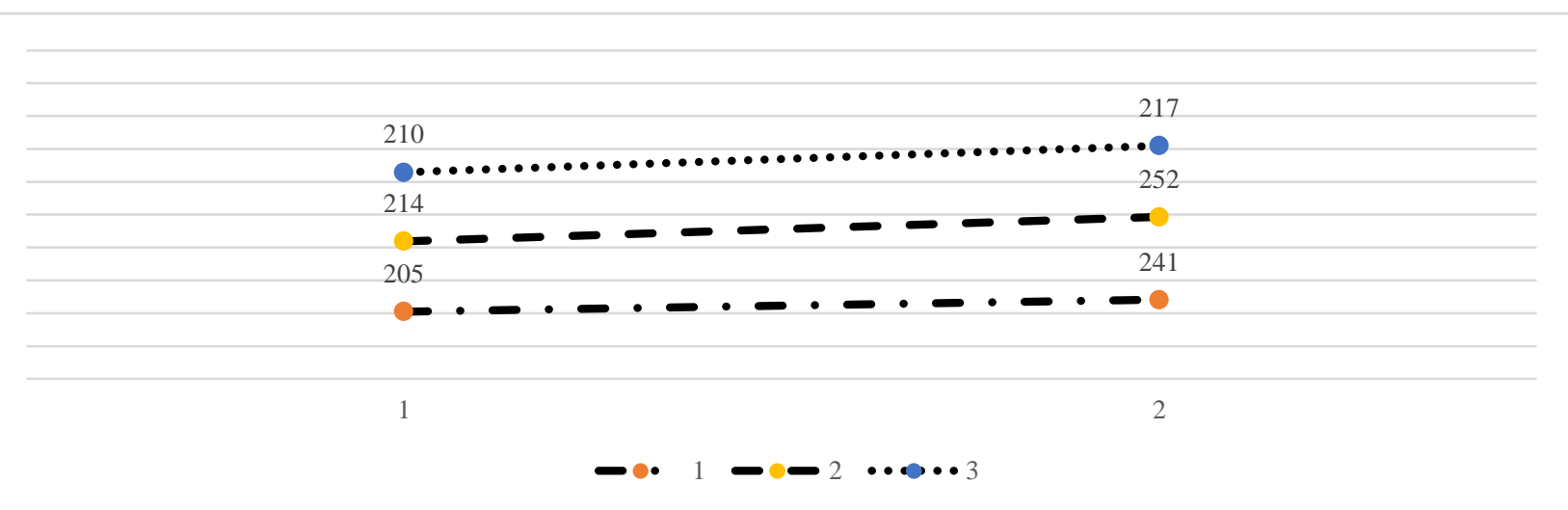

Figure 3 Age of achievement of live weight of 100 and $120 \mathrm{~kg}$, days.

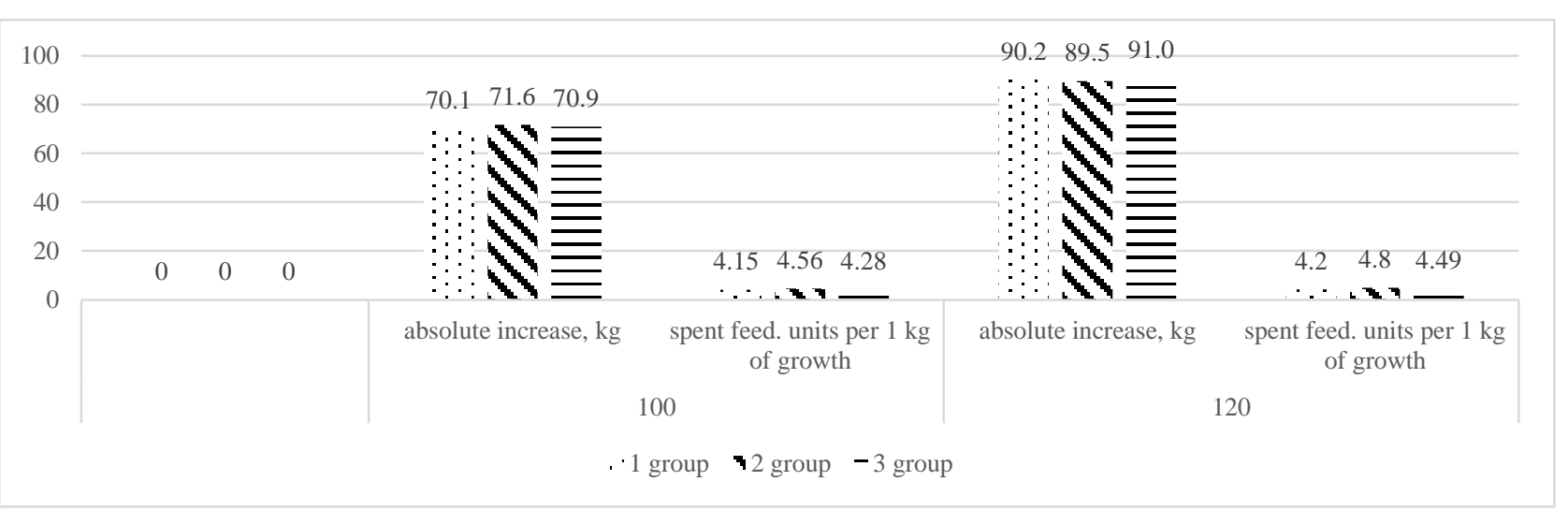

Figure 4 Feed costs and absolute increase in live weight depending on the period from the feed. 
The lack of lysine is completely eliminated when introduced into the pre-start feed of piglets $2-4$ months of age with $20 \%$ of its addition. When granulating feed for pigs, it is necessary to take into account the temperature regime, it should not exceed $50{ }^{\circ} \mathrm{C}$ since at a higher temperature there is a connection of sugar with amino acids (Shkatov, 2013).

The data obtained by us in the experiment are consistent with earlier works of (Alikaev et al., 1967; Komlatsky, 2012; Zimina, 2012; Sazonov, 2013; Sanchez, 2012) in which there is a high efficiency from the use of various components of the diet for its better digestibility, including the use of lysine in combination with methionine.

Today, the world pays great attention to the production of environmentally friendly food, including animal origin. In this regard, studies aimed at studying the increase in pork production due to the introduction of environmentally safe feed additives based on amino acids are very relevant (Komlatsky, 2012).

However, in the work of Varley (2012) it is noted that with the modern development of the pig industry, it is impossible to abandon the use of atibiotics in some cases. It is especially important to use feed antibiotics in various feed disorders to control the health of animals and reduce the impact of pathogenic microflora.

A number of Russian and foreign researchers note that for the growing organism of pigs, it is necessary to use an increased level of amino acids in the diets of feeding, including methionine and lysine. This contributes to a significant increase in metabolic processes in their body, which significantly increases the living mass in comparison with analogues that did not receive these amino acids (Ryadchikov et al., 2000; Ryadchikov et al., 2010; Omarov, 2007, Omarov et al., 2010; Ettle, et al., 2004; Moreira et al., 2004; Stein et al., 2007, Main et al., 2008, Niyazov N.S.-A., et al., 2019).

Cheryukanov, 2013 notes that reducing the level of raw protein in the diets of pigs in the growing period from 17.2 to $12.5 \%$, and in the first period of fattening from 15.0 to $11.5 \%$ and the second period of fattening from 13.0 to $10.5 \%$ is possible if the diets are balanced with synthetic amino acids lysine, threonine and methionine in an amount 24-37\% higher in comparison with detailed standards of the all-Russian Institute of animal Husbandry. This contributes not only to the normalization of the level of elemental composition of the blood, but also has a positive effect on the growth of meat productivity. Thus, the live weight of pigs increased by 18.6 and $14.3 \%$, and in the second period of fattening - by 16.5 and $14.33 \%$, than in the control group. This is consistent with the results obtained in our experiments.

Thus, justifying all of the above, we can conclude that the study and justification of the use of synthetic amino acids lysine and methionine in pig feeding will contribute to the development of diets aimed at increasing the productivity of animals. These developments will not only increase the productivity of animals, but can also be used in the development of technologies for obtaining safe food products of animal origin.

\section{CONCLUSION}

As a result of the experimental work, it was found that the lack of amino acids such as lysine and methionine in pig diets adversely affects the productivity of animals. It has been experimentally proved that when fattening pigs to 100 and $120 \mathrm{~kg}$ of live weight, it is necessary to maintain the amino acid content at the optimal level due to the introduction of synthetic amino acids, which provides an increase in live weight gain and a decrease in the age of removal from fattening. An increase in the content of a balanced amount of amino acids in the diet contributed to an improvement in the balanced composition of their meat. Thus, no significant differences $(p \leq 0.95)$ were found in the nutritional value of the resulting meat.

\section{REFERENCES}

Alikaev, V. L., Petukhov, E. A., Goleneva, L. D. Vidova, F. R. 1967. Manual control of feed quality and nutritional value of animal feed. Moskva, Russia : Kolos, 424 p.

Belous, A. A., Sermyagin, A. A., Kostyunina, O. V., Trebunskikh, E. A., Zinoviev, N. A. 2018. Genetic and paratypic factors characterizing the efficiency of feed use in duroc pigs. Agricultural Biology, vol. 53, no. 4, p. 712-722. https://doi.org/10.15389/agrobiology.2018.4.712rus

Komlatsky, G. V. 2012. Production of environmentally friendly pork. Pig Breeding, vol. 4, p. 74-76.

Kukushkin, I. Y., Filatov, A. S. 2011. Meat quality of young pigs of different breeds. Izvestia Nizhnevolzhskogo AgroUniversity Complex. vol. 2, no. 22, p. 150-154.

Kulintsev, V. V. 2011. The effect of balanced diets on essential amino acids on the productivity of young pigs. Achievements of science and technology of the agro-industrial complex. vol. 2, p. 39-40.

Kumar, A., Bhar, R., Mandal, A. B., Mendiratta, S. K. 2012. Effect of low protein diets and lysine supplementation on growth performance and carcass characteristics of growing pigs. African Journal of Biotechnology, vol. 11, no. 57, p. 12128-12134. https://doi.org/10.5897/AJB12.1024

Mysik, A. T. 2008. The current state of production and consumption of livestock products in the world. Zootechnics, vol. 1, p. 41-44.

Nikonkov, D. L., Reznichenko, A. A., Denisova, N. A., Syrovitsky, V. A. 2015. Effective protein and vitamin supplements in pig farming. Modern problems of science and education, vol. 2, no. 2, p. 7.

Sanchez, A. 2012. Biotech Hygen Pro. Pig Farming, vol. 1, p. 37.

Sazonov, M. 2013. The time has Come for the Russian prestarters. Animal Husbandry Of Russia, vol. 2. p. 52-53.

Shkatov, M. 2013. Molasses in feed for pigs. Animal husbandry of Russia, vol. 4, p. 19-20.

Smith, J. W. II., O'Quinn, P. R., Goodband, R. D., Tokach, M. D., Nelssen, J. L. 1999. The effects of low-protein, amino acid fortified diets, formulated on a net energy basis, on growth performance and carcass characteristics of finishing pigs. Journal of Applied Animal Research, vol. 15, no. 1, p. 116, https://doi.org/10.1080/09712119.1999.9706225

Strekozov, N. I., Chinarov, A. V. 2012. Our vision of the development of meat farming in Russia until 2020. Achievements of science and technology of the agro-industrial complex, vol. 8, p. 3-4.

Turyansky, A. 2003. Pig Breeding-a promising industry Economics of agriculture of Russia, vol. 6., p. 7.

Varley, M. A. 2012. Pig Progress alternative growthpromotion special. Alternatives to ATB. Asian perspective, vol. 36, no. 1, p. 14-15. 
Zimina, T. 2012. Feed industry: challenges of time. Animal husbandry of Russia, vol. 4, p. 13. https://doi.org/10.1201/b11468-3

Ryadchikov, V. G. 2006. Norms and rations for feeding farm animals, methodology, errors, prospects. J. Agricultural biology of Russia, vol. 4, p. 68-81.

Ryadchikov V., Omarov M., Polezhaev S. 2010. Ideal protein in the diets of pigs and birds. Animal Husbandry of Russia, vol. 2, p. 49-51.

Omarov, M., Golovko E., Morozov N., Kashirina M. 2007.

Balancing the diet on protein. Feeding of Farm Animals and Feed Production of Russia, vol. 6, p. 42-44.

Omarov M. O., Taranenko O. A., Golovko E. H. 2010. Ways to improve protein conversion of cake and meal. Effective Aanimal Husbandry of Russia, vol. 3, p. 25.

Niyazov, N. S.-A., Rodionova O. N. 2019. Productivity of meat-type pigs at different levels in the diet of raw protein, metabolic energy and limiting amino acids. Problems of Productive Animal Biology of Russia, vol. 2, p. 78-88. http://doi.org/10.25687/1996-6733.prodanimbiol.2019.2.78$\underline{88}$

Ettle T., Roth-Maier, D. A., Bartelt J., Roth F. X. 2004. Requirement of true ileal digestible threonine of growing and finishing pigs. J. Anim. Physiol. and Anim. Nutr., no. 88, p. 211-222. http://doi.org/10.1111/j.1439-0396.2004.00475.x

Moreira, I., Fraga A. L., Paiano D., De Oliveira G. C., Scapinello C., Martins E. N. 2004. Nitrogen balance of starting barrow pigs fed on increasing lysine. Brazilian Archives of Biology and Technology, vol. 47, no. 1, p. 85-91. http://doi.org/10.1590/S1516-89132004000100012

Stein, H. H., Sève B., Fuller M. F., Moughan, P. J., de Lange, C. F. M. 2007. Invited review: Amino acid bioavailability and digestibility in pig feed ingredients: Terminology and application. J. Anim. Sci., no. 85, p. 172180. http://doi.org/10.2527/jas.2005-742

Main, R. G., Dritz S. S., Tokach M. D., Good-band R. D., Nelssen J. L. 2008. Determining an optimum lysine:calorie ratio for barrows and gilts in a commercial finishing facility. J. Anim. Sci., vol. 86, p. 2190-2207.

Chelukanov, M. M. 2013. Influence of diets with different levels of protein and amino acids on nitrogen metabolism and productivity of growing pigs. Dissertation research work: candidate of biological sciences: 03.03.01. Borovsk, Russia, $137 \mathrm{p}$.

\section{Contact address:}

*Ivan Gorlov, Volga Region Research Institute of Manufacture and Processing of Meat-and-Milk Production, scientific adviser and Head of the Department of Food
Production Technology Volgograd State Technical University, Volgograd, Russia, Tel.: +7(8442)39-10-48,

E-mail: niimmp@mail.ru

ORCID: https://orcid.org/0000-0002-8683-8159

Marina Slozhenkina, Volga region Research Institute of production and processing of meat and dairy products, director and Professor of the Department of food production technology Volgograd state technical University, Volgograd, Russia, Tel.: +7(8442)39-10-48,

E-mail: niimmp@mail.ru

ORCID: https://orcid.org/0000-0001-9542-5893

Alexander Mosolov, Volga Region Research Institute of Manufacture and Processing of Meat-and-Milk Production, leading researcher, Volgograd, Russia, Tel.: +7(8442)39$10-48$,

E-mail: niimmp@mail.ru

ORCID: https://orcid.org/0000-0002-4927-7065

Vladimir Baranikov, Volga Region Research Institute of Manufacture and Processing of Meat-and-Milk Production, Volgograd, leading researcher, Russia, Tel.: +7(8442)39$10-48$,

E-mail: niimmp@mail.ru

ORCID: https://orcid.org/0000-0003-2203-7261

Dmitry Nikolaev, Volga Region Research Institute of Manufacture and Processing of Meat-and-Milk Production, Volgograd, Russia, Tel.: +7(8442)39-10-48,

E-mail: dmitriynikolaev1978@yandex.ru

ORCID: https://orcid.org/0000-0001-9283-5299

Alexander Chernyak, Volga Region Research Institute of Manufacture and Processing of Meat-and-Milk Production, applicant, Volgograd, Russia, Tel.: +7(8442)39-10-48,

E-mail: niimmp@mail.ru

ORCID: https://orcid.org/0000-0002-1818-2725

Bogdan Sherstyuk, Volga Region Research Institute of Manufacture and Processing of Meat-and-Milk Production, applicant, Volgograd, Russia, Tel.: +7(8442)39-10-48,

E-mail: bonsher909@mail.ru,

ORCID: https://orcid.org/0000-0001-9121-1708

Olga Krotova, Volga Region Research Institute of Manufacture and Processing of Meat-and-Milk Production, senior researcher, Volgograd, Russia, Tel.: +7(8442)39$10-48$,

E-mail: niimmp@mail.ru

ORCID: https://orcid.org/0000-0002-2476-1395

Corresponding author: * 